\title{
Pengaruh Negatif Game Online Terhadap Motivasi Belajar Siswa di SMKN 1 Narmada
}

\author{
Komang Sundara', Hafsah², Muhamad Ahlun Nasar ${ }^{3}$ \\ ${ }^{1}$ Pendidikan Pancasila dan Kewarganegaraan Universitas Muhammadiyah Mataram Email : komangsundara@gmail.com \\ ${ }^{2}$ Pendidikan Pancasila dan Kewarganegaraan Universitas Muhammadiyah Mataram Email : dansa machi@yahoo.co.id \\ ${ }^{3}$ Pendidikan Pancasila dan Kewarganegaraan Universitas Muhammadiyah Mataram Email : ahlun.nazar212@gmail.com
}

INFO ARTIKEL
Riwayat Artikel:
Diterima: 14 September
2020
Disetujui: 30 September
2020

\section{Kata Kunci:}

Pengaruh negatif

Game online

Motivasi belajar

\begin{abstract}
ABSTRAK
Abstrak: Game Online adalah salah satu jenis permainan yang memanfaatkan perangkat yang terkoneksi jaringan internet sebagai medianya. Adanya Game Online saat ini, menjadi suatu tantangan baru bagi para pelajar, hal ini dikarenakan pada masa ini adalah masa perkembangan. Persoalan Motivasi bagi remaja maupun anak-anak adalah persoalan yang paling umum, pembangunan motivasi belajar menjadi suatu tantangan baru bagi remaja dan anak-anak selaku siswa-siswi sebagai peserta didik, salah satunya siwa-siswi SMKN 1 Narmada. Penelitian ini bertujuan untuk mengetahui pengaruh negatif game online terhadap motivasi belajar siswa di SMKN 1 Narmada Tahun Pelajaran 2019/2020. Metode yang digunakan dalam penelitian ini yaitu menggunakan jenis penelitian kuantitatif dengan pendekatan korelasional kausal. Dengan populasi sebanyak 47 siswa kelas $X$ dan teknik samping adalah Proportionate Random Sampling (pengambilan sampel secara seimbang) yaitu sebanyak 40 siswa dari kelas $X$. Metode pengumpulang data yaitu kuesioner (angket) dan dokumentasi. Berdasarkan hasil uji hipotesis dengan Uji T didapatkan hasil t hitung yaitu sebesar $-5,485$ Jika dibandingkan $t$ tabel dengan jumlah $\mathrm{N} 40$ pada pada a 0,05 uji satu pihak, $\mathrm{dk}=\mathrm{n}-1=40-1=39$ yaitu sebesar $-1,685$ yang berarti $5,485<-1,685$ (t hitung lebih kecil dari t tabel). Dapat disimpulkan bahwa Ho yang berbunyi tidak terdapat pengaruh negatif game online terhadap motivasi belajar siswa di SMKN 1 Narmada tahun pelajaran 2019/2020 ditolak dan Ha yang berbunyi terdapat pengaruh negatif game online terhadap motivasi belajar siswa di SMKN 1 Narmada tahun pelajaran 2019/2020 diterima.
\end{abstract}

\begin{abstract}
An online game is a type of game that uses a device connected to the internet as the medium. The existence of Online Games nowadays becomes a new challenge for students because they are in a period of development. Motivation issues for adolescents and teenagers are the most common problems. The development of learning motivation is a new challenge for adolescents and teenagers as students, one of which is the students of SMKN 1 Narmada. This study aimed to determine the negative effect of online games on student learning motivation at SMKN 1 Narmada in the 2019/2020 academic year. This research used a quantitative approach with a causal correlational method. The population consists of 47 students in class $X$. The sampling technique used was Proportionate Random Sampling (taking a balanced sample) by taking 40 students from class $X$. The data collection methods used were questionnaires and documentation. Based on the results of the t-test, it is found that $t$-test result is -5.485 When compared to the $t$ table with $N 40$ at $\alpha 0.05$, the one-party test, $d k=n-1=40-1=39$, which is equal to -1.685 which means $-5,485<-1,685$ (t-test is smaller than $t$ table). It can be concluded that $\mathrm{Ho}$, which says there is no negative effect of online games on student learning motivation at SMKN 1 Narmada in the 2019/2020 academic year, is rejected. Ha, which says there is a negative effect of online games on student learning motivation at SMKN 1 Narmada in the 2019/2020 academic year, is accepted.
\end{abstract}

\section{A. LATAR BELAKANG}

Game Online pada dasarnya berfungsi untuk menghilangkan kepenatan atau sekedar melakukan penyegaran otak setelah melaksanakan aktivitas seharihari. Namun pada kenyataannya, permainan tersebut justru membuat individu menjadi terikat. Intensitas bermain game online yang tinggi membuat individu mengalami kecanduan yang berdampak terhadap perilaku individu. Beberapa dampak negatif akibat tingginya intensitas bermain game online yaitu remaja menjadi tidak memiliki prioritas yang tinggi dalam menjalani aktivitas sehari-hari, mendorong remaja bertindak asosial, serta menyebabkan remaja menjadi malas untuk belajar.[1]

Hasil beberapa penelitian sebelumnya menemukan ada pengaruh negatif yang signifikan game online terhadap prestasi akademik peserta didik, Pengaruh negatif tersebut sesuai dengan teori bahwa prestasi 
akademik dapat dipengaruhi oleh dua faktor, yaitu faktor eksternal dan internal. Salah satu faktor eksternal yaitu lingkungan yang terdiri dari masyarakat salah satunya adalah teman bergaul dan faktor internal yaitu kecerdasan, minat dan motivasi.[2][3] Ada pengaruh negatif dari bermain game online dengan perilaku sosial dan prestasi belajar siswa.[4] Menurunyannya prestasi belajar siswa dipengaruhi oleh permainan game online dan juga didikan orang tua perlu insentif dalam mengawasi permainan anak.[5] pengaruh game online berdampak pada adanya penurunan prestasi belajar siswa.[6]

Penelitiam mereka lebih kajian pada aspek pengaruh negative game online terhadap siswa, hubungan game online dengan perilaku social siswa dan hasil belajar, dampak game online terhadap prestasi belajar siswa SMP. Sementara aspek dampak permainan game online pada kalangan siswa SMA di Lombok Barat masih kurang yang melakukan penelitian, karena di Lombok barat khusus pada siswa SMK sangat tinggi permainan game online. Game Online mengambil alih perhatian banyak remaja dan anak-anak sehingga membawa sebuah perubahan besar terhadap jenis permainan anak sekarang ini. Efektivitas Game Online merubah jenis permainan sangat besar, terbukti dari pengamatan pribadi peneliti yang melihat kondisi remaja dan anakanak dalam lingkungan masyarakat yang sudah sangat candu terhadap game online, permainan-permainan tradisional seperti sepak bola sudah semakin sedikit peminatnya karena peranan Game Online yang sudah merajai permainan dari berbagai kalangan.

Adanya Game Online saat ini, menjadi suatu tantangan baru bagi para pelajar seperti siswa-siswi Sekolah Dasar sampai Sekolah Menengah Atas/Sekolah Menengan Kejuruan, hal ini dikarenakan pada masa ini adalah masa perkembangan. Dalam psikologi salah satu faktor yang mempengaruhi perkembangan adalah menurut paham konvergensi bahwa didalam perkembangan individu baik dasar atau pembawaan maupun lingkungan memainkan peranan yang sangat penting.[7] Setiap individu memiliki kondisi internal, dimana kondisi internal tersebut turut berperan dalam aktivitas dirinya setiap harinya, salah satu dari kondisi internal tersebut adalah motivasi.[8] Selain itu unsurunsur yang mempengaruhi motivasi belajar yaitu citacita atau aspirasi siswa, kemampuan siswa, kondisi siswa, kondisi lingkungan siswa, unsur-unsur dinamis dalam belajar pembelajaran, dan upaya guru dalam membelajarkan siswa.[9] Motivasi belajar merupakan insting yang mendorong untuk beraktivitas lebih baik dan giat terhadap belajar, berbuat, berperilaku dan bertingkah sesame orang lain, benda atau alat komunikasi.[10]

Pelajar yang sering memainkan suatu Game Online akan menyebabkan menjadi ketagihan. Pelajar yang sering bermain Game Online akan mengalami ketergantungan pada aktivitas game yang mengurangi waktu dan keinginan untuk belajar. Hal tersebut menggambarkan bahwa kehadiran Game Online membawa dampak negatif yang dapat mempengaruhi motivasi belajar.[11]

Persoalan Motivasi bagi remaja maupun anak-anak adalah persoalan yang paling umum, pembangunan motivasi belajar menjadi suatu tantangan baru bagi remaja dan anak-anak selaku siswa-siswi sebagai peserta didik. Hal ini disebabkan karena terlahirnya gaya baru dalam Jenis permainan, Game Online mengambil peranan penting karena sudah menjadi suatu candu dikalangan remaja dan anak-anak yang masih sekolah.

Berkaitan dengan hal-hal di atas berdasarkan observasi awal dengan mewawancarai salah satu siswa yang bermain Game Online dan salah satu guru, peneliti mendapat informasi bahwa di SMKN 1 Narmada memiliki siswa-siswa yang memainkan Game Online dengan jumlah yang lumayan besar, dimana pengaruh game online terhadap motivasi sangat dirasakan, salah satu contohnya siswa yang sering bermain Game Online motivasi belajarnya sangat menurun hal itu bisa dilihat kemampuan memahami materi yang disampaikan oleh guru masih sangat kurang, bisa dilihat dari kurangnya keaktifan siswa dalam proses pembelajaran dan nilai siswa yang rata-rata hanya memperoleh pada standar KKM yaitu 75, hal ini menjadi pertanda bahwa tidak ada dorongan atau semakin rendahnya motivasi belajar siswa.

Memperhatikan fenomena ataupun persoalan Game Online beserta dampaknya bagi kehidupan yang saat ini sangat memprihatinkan termasuk di Kabupaten Lombok Barat, oleh karena itu, sangat penting dilakukan kajian mendalam untuk mendapatkan hasil pengaruh game online terhadap prestasi belajar siswa SMAN 1 Narmada di kabupaten Lombok Barat yang kondisi siswa cukup beragam, dan motivasi siswa bermain game online tinggi. tujuan dalam artikel ini adalah untuk menjelaskan pengaruh negatif game online terhadap motivasi belajar siswa di SMKN 1 Narmada tahun pelajaran 2019/2020.

Terdapat 3 kategori yang mempengaruhi motivasi belajar antara lain yaitu, Intensitas bermain game online, waktu bermain dan game online yang digemari.[12] Ciriciri motivasi yang ada pada siswa di antaranya adalah: 1) Tekun menghadapi tugas (dapat bekerja terus-menerus dalam waktu yang lama, tidak pernah berhenti sebelum selesai). 2) Ulet menghadapi kesulitan (tidak lekas putus asa) tidak memerlukan dorongan dari luar untuk berprestasi sebaik mungkin (tidak cepat puas dengan prestasi yang telah dicapainya). 3) Menunjukkan minat terhadap bermacam-macam masalah. 4) Lebih senang bekerja mandiri. 5) Cepat bosan pada tugas yang rutin (hal-hal yang bersifat mekanis, berulang-ulang begitu sajasehingga kurang efektif). 6) Dapat mempertahankan pendapatnya (kalau sudah yakin akan sesuatu). 7) Tidak mudah melepaskan hal yang diyakini itu. 8) Senang mencari dan memecahkan masalah soal-soal.[13] 
Berdasarkan hal diatas dapat ditarik suatu indikator Motivasi Belajar sebagai berikut (a) Teguh dalam menghadapi tugas. (b) Ulet menghadapi kesulitan. (c) Menunjukan minat terhadap bermacam-macam masalah. (d) Cepat bosan dengan tugas yang rutin. (e) Lebih senang bekerja mandiri. (f) Dapat mempertahankan pendapatnya. (g) Senang mencari dan memecahkan masalah soal-soal. (h) Adanya hasrat dan keinginan untuk berhasil.

\section{B. METODE PENELITIAN}

\section{Jenis Penelitian}

Pemilihan metode pada penelitian ini menggunakan jenis penelitian kuantitatif dengan pendekatan korelasi. Lokasi penelitian yang digunakan sebagai obyek adalah SMKN 1 Narmada, yang beralamat di jln. Ahmad Yani No. 23 Narmada Lombok Barat, Kelurahan Peresak, Kec. Narmada, Kab. Lombok Barat, NTB.

\section{Populai dan Sampel}

Populasi pada penelitian ini adalah semua siswa kelas X di SMKN 1 Narmada yang bermain Game Online yaitu sejumlah 47 orang. teknik sampling yang digunakan adalah Proportionate Random Sampling yaitu teknik penentuan sampel secara seimbang mengikuti besar kecilnya masing-masing sub populasi penelitian[14]. Berkaitan dengan hal tersebut berdasarkan tabel penentuan jumlah sampel dari populasi tidak terdapat jumlah $(\mathrm{N})$ sebesar 47 sehingga memilih jumlah $(\mathrm{N})$ terdekat yaitu $=45$ pada taraf kesalahan $5 \%$ didapat jumlah sampel (S) yaitu $=40$.

\section{Identifikasi Variabel}

Berkaitan dengan penelitian ini ada dua jenis variabel penelitian yang digunakan yaitu Game Online sebagai variabel bebas (Independent) dan Motivasi Belajar sebagai variabel terikat (Dependent). Game online adalah sebuah permainan (games) yang dimainkan didalam suatu jaringan (baik LAN maupun Internet) yang bisa dimainkan oleh banyak pemain (multiplayer). Realitas dampak negatif game online dapat dilihat dari intensitas bermain game online (tinggi), waktu bermain game online (tinggi), dan game online yang digemari, sehingga dapat menimbulkan adiksi, mendorong melakukan hal-hal negatif, berbicara kasar dan kotor, terbengkalainya kegiatan di dunia nyata, perubahan pola makan/istrahat, pemborosan dan mengganggu kesehatan. Sedangkan Motivasi belajar adalah dorongan untuk melakukan perubahan tingkah laku dalam belajar. Motivasi belajar ditunjukan dengan ciri-ciri: teguh dalam menghadapi tugas, ulet menghadapi kesulitan, menunjukan minat terhadap bermacam-macam masalah, cepat bosan dengan tugas yang rutin, lebih senang bekerja mandiri, dapat mempertahankan pendapatnya, senang mencari dan memecahkan masalah soal-soal dan adanya hasrat dan keinginan untuk berhasil.

\section{Metode Pengumpulan Data dan Instrument}

Metode pengumpulan data pada penelitian ini adalah dengan menggunakan Angket dan Dokumentasi. Bentuk Instrument dalam penelitian ini yaitu Skala Likert. Adapun bentuk skala dari penelitian ini berupa pertanyaan dengan lima alternatif jawaban yaitu: Sangat Setuju (SS), Setuju (ST), Kurang Setuju (KS), Tidak Setuju (TS) dan Sangat Tidak Setuju (STS). Masing-masing jawaban tersebut diberi skor dari 5 smpai 1 jika bentuk pertanyaan yang positif, sebaliknya jika berbentuk pertanyaan yang negatif diberi skor dari 1 sampai 5 . Untuk variabel game online menggunakan 25 Item pernyataan dan untuk variabel motivasi belajar yaitu menggunakan 27 item pernyataan.

Tabel 1

Hasil Uji Validasi Instrument Game Online

\begin{tabular}{|c|c|c|c|}
\hline No. & r Tabel & r Hitung & Keterangan \\
\hline 1 & 0,312 & 0,777 & Valid \\
\hline 2 & 0,312 & 0.763 & Valid \\
\hline 3 & 0,312 & 0,824 & Valid \\
\hline 4 & 0,312 & o,672 & Valid \\
\hline 5 & 0,312 & $-0,141$ & Tidak Valid \\
\hline 6 & 0,312 & 0,731 & Valid \\
\hline 7 & 0,312 & 0,393 & Valid \\
\hline 8 & 0,312 & 0,681 & Valid \\
\hline 9 & 0,312 & 0,593 & Valid \\
\hline 10 & 0,312 & 0,611 & Valid \\
\hline 11 & 0,312 & 0,615 & Valid \\
\hline 12 & 0,312 & 0,580 & Valid \\
\hline 13 & 0,312 & o,6o6 & Valid \\
\hline 14 & 0,312 & 0,629 & Valid \\
\hline 15 & 0,312 & 0,646 & Valid \\
\hline 16 & 0,312 & 0,391 & Valid \\
\hline 17 & 0,312 & 0,174 & Tidak Valid \\
\hline 18 & 0,312 & 0,670 & Valid \\
\hline 19 & 0,312 & 0,753 & Valid \\
\hline 20 & 0,312 & 0,571 & Valid \\
\hline 21 & 0,312 & 0,496 & Valid \\
\hline 22 & 0,312 & 0,809 & Valid \\
\hline 23 & 0,312 & 0,791 & Valid \\
\hline 24 & 0,312 & $-0,110$ & Tidak Valid \\
\hline 25 & 0,312 & 0,515 & Valid \\
\hline 26 & 0,312 & 0,648 & Valid \\
\hline 27 & 0,312 & $-0,325$ & Tidak Valid \\
\hline 28 & 0,312 & 0,718 & Valid \\
\hline 29 & 0,312 & 0,592 & Valid \\
\hline 30 & 0,312 & 0,179 & Tidak Valid \\
\hline
\end{tabular}


Berdasarkan tabel diatas dapat disimpulkan bahwa variabel game online yang terdiri dari 30 pernyataan, yang valid berjumlah 25 dan pernyataan yang tidak valid ada 5 yaitu pada no 5, 17, 24, 27 dan 30. Selanjutnya, pernyataan yang digunakan untuk penelitian adalah pernyataan yang sudah valid, untuk itu peneliti menggunakan 25 pernyataan.

Tabel 2

Hasil Uji Validasi Instrument Motivasi Belajar

\begin{tabular}{cccc}
\hline No. & r Tabel & r Hitung & Keterangan \\
\hline 1 & 0,312 & 0,841 & Valid \\
2 & 0,312 & 0,766 & Valid \\
3 & 0,312 & 0,807 & Valid \\
4 & 0,312 & 0,222 & Tidak Valid \\
5 & 0,312 & 0,199 & Tidak Valid \\
6 & 0,312 & 0,378 & Valid \\
7 & 0,312 & 0,218 & Tidak Valid \\
8 & 0,312 & 0,492 & Valid \\
9 & 0,312 & 0,151 & Tidak Valid \\
10 & 0,312 & 0,713 & Valid \\
11 & 0,312 & 0,581 & Valid \\
12 & 0,312 & 0,779 & Valid \\
13 & 0,312 & 0,238 & Tidak Valid \\
14 & 0,312 & $-0,151$ & Tidak Valid \\
15 & 0,312 & 0,506 & Valid \\
16 & 0,312 & 0,794 & Valid \\
17 & 0,312 & 0,556 & Valid \\
18 & 0,312 & $-0,064$ & Tidak Valid \\
19 & 0,312 & 0,477 & Valid \\
20 & 0,312 & 0,537 & Valid \\
21 & 0,312 & 0,655 & Valid \\
22 & 0,312 & 0,348 & Valid \\
23 & 0,312 & $-0,085$ & Tidak Valid \\
24 & 0,312 & 0,194 & Tidak Valid \\
25 & 0,312 & 0,426 & Valid \\
26 & 0,312 & 0,766 & Valid \\
27 & 0,312 & 0,235 & Tidak Valid \\
28 & 0,312 & 0,403 & Valid \\
29 & 0,312 & 0,394 & Valid \\
30 & 0,312 & 0,581 & Valid \\
31 & 0,312 & 0,042 & Tidak Valid \\
32 & 0,312 & 0,199 & Tidak Valid \\
33 & 0,312 & $-0,024$ & Tidak Valid \\
34 & 0,312 & 0,868 & Valid \\
35 & 0,312 & 0,142 & Tidak Valid \\
36 & 0,312 & $-0,534$ & Tidak Valid \\
37 & 0,312 & $-0,042$ & Tidak Valid \\
38 & 0,312 & $-0,319$ & Tidak Valid \\
39 & 0,312 & 0,342 & Valid \\
40 & 0,312 & 0,357 & Valid \\
41 & 0,312 & 0,312 & Tidak Valid \\
\hline & & & \\
3 & & \\
3 & & \\
3 & &
\end{tabular}

\begin{tabular}{cccc}
\hline 42 & 0,312 & 0,433 & Valid \\
43 & 0,312 & 0,483 & Valid \\
44 & 0,312 & 0,443 & Valid \\
45 & 0,312 & 0,084 & Tidak Valid \\
46 & 0,312 & 0,287 & Tidak Valid \\
47 & 0,312 & 0,417 & Valid \\
48 & 0,312 & 0,109 & Tidak Valid \\
\hline
\end{tabular}

Berdasarkan tabel diatas dapat disimpulkan bahwa item pernyataan variabel motivasi belajar yang terdiri dari 48 pernyataan, yang valid berjumlah 27 dan pernyataan yang tidak valid ada 21 yaitu pada nomor 4, 5, 7, 9, 13, 14, 18, 23, 24, 27, 31, 32, 33, 35, $36,37,38,41,45,46$ dan 48 . Selanjutnya pernyataan yang digunakan untuk penelitian adalah pernyataan yang sudah valid, untuk itu peneliti menggunakan 27 pernyataan.

\section{Metode Analisis Data \\ a. Deskripsi Data}

pendeskripsian data pada penelitian ini yaitu dengan menggunakan tabel. Selanjutnya mencari nilai mean dan standar deviasi dengan dibantu program IMB SPSS (Statistical Package for the Social Sciences) 25, kemudian mengelompokan frekuensi skor siswa dalam skala 5 (sangat tinggi, tinggi, sedang, kurang dan sangat kurang).

\section{b. Uji Prasyarat}

Dalam penelitian ini pengujian normalitas menggunakan rumus jenis konglogrov-smirnov, dengan dibantu program IMB SPSS (Statistical Package for the Social Sciences) 25, dalam hal ini untuk mengetahui apakah suatu data terdistribusi secara normal adalah jika signifikan (signisficance level) lebih besar dari 0,05 (sign> 0,05).

\section{c. Uji Hipotesis}

Pengujian hipotesis dan mengetahui signifikansi pada penelitian ini maka dilakukan pengujian hipotesis direksional atau uji pihak kiri (one tail test). Pengujian ini dilakukan dengan menggunakan Uji $\mathrm{T}$ dibantu program IMB SPSS (Statistical Package for the Social Sciences) 25 dengan tingkat kepercayaan sebesar 0,05 dan berdasarkan kriteria sebagai berikut:

1. Jika $t$ hitung $\geq t$ tabel ( $t$ hitung lebih besar dari $t$ tabel) maka Ho diterima dan Ha ditolak yang berarti tidak terdapat pengaruh negatif antara $\mathrm{X}$ dengan $Y$.

2. Jika $\mathrm{t}$ hitung $<\mathrm{t}$ tabel ( $\mathrm{t}$ hitung lebih kecil dari $\mathrm{t}$ tabel) maka Ho ditolak dan Ha diterima yang berarti terdapat pengaruh negatif antara $\mathrm{X}$ dengan Y.

\section{HASIL DAN PEMBAHASAN \\ 1. Deskripsi Data}




\section{a. Game Online}

Untuk mengetahui mean, nilai maksimum, nilai minimum, dan standar deviasi, dari hasil angket game online dibantu dengan program IMB SPSS 25 dan dapat dijabarkan sebagai berikut :

\section{Tabel 3}

Hasil Deskripsi Statistik

\begin{tabular}{lrrrrr}
\hline \multicolumn{5}{c}{ Descriptive Statistics } \\
\hline & N & Minimum & Maximum & Mean & $\begin{array}{c}\text { Std. } \\
\text { Deviation }\end{array}$ \\
\hline $\begin{array}{l}\text { Game online } \\
\text { Valid N } \\
\text { (listwise) }\end{array}$ & 40 & 43 & 121 & 85,63 & 17,621 \\
\hline
\end{tabular}

Berdasarkan tabel di atas untuk variabel game online dapat disimpulkan bahwa skor minimum 43, skor maksimum 121, mean 85,63 dan standar deviation 17,621. Selanjutnya, untuk menentukan katagori dari tingkat bermain game online, dapat dilihat dari penjelasan dibawah ini:

\section{Tabel 4}

Frekuensi katagori bermain game online

\begin{tabular}{ccccc}
\hline NO & $\begin{array}{c}\text { Kelas } \\
\text { Interval }\end{array}$ & Frekuensi & $\begin{array}{c}\text { Presentase } \\
\%\end{array}$ & Kategori \\
\hline 1 & $43-58$ & 2 & 5 & $\begin{array}{c}\text { Sangat } \\
\text { Rendah }\end{array}$ \\
2 & $59-74$ & 6 & 15 & Rendah \\
3 & $75-90$ & 18 & 45 & Sedang \\
4 & $91-106$ & 10 & 25 & Tinggi \\
5 & $107-122$ & 4 & 10 & Sangat \\
& & 40 & $100 \%$ & Tinggi \\
\hline
\end{tabular}

Berdasarkan tabel di atas dapat disimpulkan bahwa tingkat bermain game online siswa dalam kelas interval 75 -90 mendominasi dengan jumlah 18 siswa dan frekuensi $45 \%$, dengan ini dapat dikatakan bahwa tingkat bermain game online siswa dalam katagori sedang.

\section{b. Motivasi Belajar}

Untuk mengetahui mean, nilai maksimum, nilai minimum, dan standar deviasi, dari hasil angket motivasi belajar dibantu dengan program IMB SPSS 25 dan dapat dijabarkan sebagai berikut:

\section{Tabel 5}

Hasil Deskripsi Statistik

$$
\text { Descriptive Statistics }
$$

Std. N Minimum Maximum Mean Deviation

\begin{tabular}{llllll}
\hline Motivasi & & & & & \\
Belajar & 40 & 60 & 109 & 83,48 & 12,874 \\
Valid N & & & & & \\
(listwise) & 40 & & & & \\
\hline
\end{tabular}

Berdasarkan tabel di atas untuk variabel motivasi belajar dapat disimpulkan bahwa skor minimum 60, skor maksimum 109, mean 83,48 dan standar deviation 12,874. Selanjutnya, untuk menentukan katagori dari tingkat motivasi belajar, dapat dilihat dari penjelasan dibawah ini:

Tabel 6

Frekuensi katagori motivasi belajar

\begin{tabular}{ccccc}
\hline N & $\begin{array}{c}\text { Kelas } \\
\text { Interva } \\
\text { O }\end{array}$ & $\begin{array}{c}\text { Frekuen } \\
\mathbf{1}\end{array}$ & $\begin{array}{c}\text { si } \\
\text { Presenta } \\
\text { se \% }\end{array}$ & $\begin{array}{c}\text { Katego } \\
\text { ri }\end{array}$ \\
\hline \multirow{2}{*}{1} & $60-69$ & 7 & 17,5 & $\begin{array}{c}\text { Rendah } \\
\text { Rendah }\end{array}$ \\
2 & $70-79$ & 5 & 12,5 & Sedang \\
3 & $80-89$ & 19 & 47,5 & Tinggi \\
4 & $90-99$ & 3 & 7,5 & Sangat \\
& $100-$ & & & Tinggi \\
5 & 109 & 6 & 15 & \\
& Jumlah & 40 & $100 \%$ & \\
\hline
\end{tabular}

Berdasarkan tabel di atas dapat disimpulkan bahwa tingkat motivasi belajar siswa dalam kelas interval 80 89 mendominasi dengan jumlah 19 siswa dan presentase $47,5 \%$, dengan ini dapat dikatakan bahwa tingkat motivasi belajar siswa dalam kategori sedang.

\section{Uji Prasyarat}

Sebelum melakukukan uji hipotesis terlebih dahulu data harus berdistribusi normal, sebegai prasyarat dalam menganalis menggunakan statistik parametrik. Uji Normalitas data variabel game online dan variabel motivasi belajar pada penelitian ini dilakukan dengan menggunakan rumus Konglogrovsmirnov dengan bantuan program IMB SPSS 25, pengambilan keputusan berdasar pada kritria yaitu jika nilai sig $_{\text {hitung }}>0,05$ maka data berdistribusi normal.

Berikut ini pengujian normalitas variabel game online dan motivasi belajar, dapat dilihat pada tabel berikut.

Tabel 7

Uji Normalitas

\begin{tabular}{ll|r|r}
\hline \multicolumn{3}{c}{ One-Sample Kolmogorov-Smirnov Test } \\
& & Game & Motivasi \\
\hline N & & 40 & 40 \\
Normal Parameters & Mean & 85,63 & 83,48 \\
& Std. Deviation & 17,621 & 12,874 \\
Most Extreme Differences & Absolute &, 119 &, 109 \\
& Positive &, 119 &, 109 \\
& Negative &,- 109 &,- 094 \\
Test Statistic & &, 119 &, 109 \\
Asymp. Sig. (2-tailed) & &, $161^{\mathrm{c}}$ &, $200^{\mathrm{c}, \mathrm{d}}$ \\
\hline
\end{tabular}

Berdasarkan hasil uji normalitas pada tabel di atas, diperoleh hasil sebagai berikut:

1) Nilai Sig. variabel game online $0,161>0,05$

2) Nilai Sig. variabel motivasi belajar $0,200>0,05$.

Dengan hasil tersebut dapat disimpulkan bahwa kedua variabel pada model kolmogorov-smirnov berdistribusi normal.

\section{Uji Hipotesis}


Pengujian ini dilakukan dengan Uji $\mathrm{T}$, untuk mengetahui signifikansi pada penelitian ini maka dilakukan pengujian hipotesis direksional atau uji pihak kiri (one tail test) dengan tingkat kepercayaan sebesar 0,05 dan dengan berdasarkan kriteria sebagai berikut:

1. Jika $t$ hitung $\geq \mathrm{t}$ tabel ( $\mathrm{t}$ hitung lebih besar dari $\mathrm{t}$ tabel) maka Ho diterima dan Ha ditolak yang berarti tidak terdapat pengaruh negatif game online terhadap motivasi belajar siswa di SMKN 1 Narmada tahun pembelajaran 2019/2020.

2. Jika t hitung $<\mathrm{t}$ tabel ( $\mathrm{t}$ hitung lebih kecil dari $\mathrm{t}$ tabel) maka Ho ditolak dan Ha diterima yang berarti terdapat pengaruh negatif game online terhadap motivasi belajar siswa di SMKN 1 Narmada tahun pembelajaran 2019/2020.

\section{Tabel 8}

Hasil Uji T

\begin{tabular}{|c|c|c|c|c|c|}
\hline \multicolumn{6}{|c|}{ Coefficients $^{\mathbf{a}}$} \\
\hline \multirow[t]{3}{*}{ Model } & \multirow{2}{*}{\multicolumn{2}{|c|}{$\begin{array}{l}\text { Unstandardiz } \\
\text { ed } \\
\text { Coefficients }\end{array}$}} & \multirow{3}{*}{$\begin{array}{l}\text { Standardiz } \\
\text { ed } \\
\text { Coefficients } \\
\text { Beta }\end{array}$} & \multirow[t]{3}{*}{$\mathrm{t}$} & \multirow[t]{3}{*}{$\begin{array}{l}\mathrm{Si} \\
\mathrm{g} .\end{array}$} \\
\hline & & & & & \\
\hline & B & $\begin{array}{l}\text { Std. } \\
\text { Error }\end{array}$ & & & \\
\hline 1 (Constant & 125,05 & 7,737 & & 16,164 & ,00 \\
\hline ) & 8 & & & & $\mathrm{o}$ \\
\hline Game &,- 486 & 08 &,- 665 & $-5,485$ & , oo \\
\hline
\end{tabular}

a. Dependent Variable: Motivasi

Berdasarkan hasil perhitungan di atas bahwa $\mathrm{t}$ hitung sebesar $-5,485$, jika dibandingkan $t$ tabel dengan jumlah N 40 pada $\alpha$ o,05 uji satu pihak, $\mathrm{dk}=\mathrm{n}-1=40-$ 1 = 39 yaitu sebesar $-1,685$. Hal tersebut berarti $-5,485<$ $-1,685$ ( $t$ hitung lebih kecil dari $t$ tabel). Dapat disimpulkan bahwa Ho yang berbunyi tidak terdapat pengaruh negatif game online terhadap motivasi belajar siswa di SMKN 1 Narmada tahun pembelajaran 2019/2020 ditolak dan Ha yang berbunyi terdapat pengaruh negatif game online terhadap motivasi belajar siswa di SMKN 1 Narmada tahun pembelajaran 2019/2020 diterima.

\section{Pembahasan}

Hasil perhitungan uji hipotesis dengan menggunakan rumus Uji T menunjukan bahwa nilai -t hitung sebesar $5,485<-1,685$ dengan demikian dapat disimpulkan bahwa terdapat pengaruh negatif yang signifikan antara game online dengan motivasi belajar siswa di SMKN 1 Narmada tahun pembelajaran 2019/2020. Hal tersebut sesuai dengan pendapat Surbakti menyebutkan salah satu dampak negatif game online adalah terbengkalainya kegiatan di dunia nyata, keterikatan pada waktu bermain game online dan rasa asyik memainkannya seringkali membuat berbagai kegiatan terbengkalai, seperti waktu untuk belajar dan mengerjakan tugas sekolah[11]. Lebih lanjut Menurut Dimyati \& Mudjiono salah satu unsurunsur yang mempengaruhi motivasi belajar siswa yaitu kondisi lingkungan siswa, keadaan atau kondisi lingkungan siswa yang baik akan memperkuat motivasi belajar sebaliknya keadaan lingkungan siswa yang tidak baik akan menurunkan motivasi belajar siswa.[9] Artinya game online sebagai salah satu lingkungan negatif siswa dapat menurunkan motivasi belajar pada siswa.

Game online akan mengurangi aktivitas positif yang seharusnya dijalani oleh anak pada usia perkembangan mereka. Anak yang mengalami ketergantungan pada aktivitas games, akan mempengaruhi motivasi belajar sehingga mengurangi waktu belajar dan waktu untuk bersosialisasi dengan teman sebaya mereka.[3];[15] Oleh karena itu tingginya intensitas, waktu dan keterikatan individu (siswa) dalam bermain game online maka akan semakin rendah motivasi belajarnya, dengan demikian game online sangat berpengaruh negatif terhadap motivasi belajar siswa. Adanya game online sangat mempengaruhi perilaku belajar siswa.[16];[17].

\section{SIMPULAN DAN SARAN}

Penelitian ini dilakukan untuk mengetahui pengaruh negatif game onine terhadap motivasi belajar siswa di SMKN 1 Narmada tahun pembelajaran 2019/2020. Berdasarkan uji hipotesis menggunakan rumus Uji T dengan dibantu program IMB SPSS 25 diperoleh niai t hitung sebesar $-5,485$ yaitu lebih kecil dari nilai t tabel pada $\mathrm{N} 40$ pada pada $\alpha 0,05$ uji satu pihak, $\mathrm{dk}=\mathrm{n}-1=40$ $-1=39$ yaitu sebesar $-1,685$, yang berarti Ho yang berbunyi tidak terdapat pengaruh negatif game online terhadap motivasi belajar siswa di SMKN 1 Narmada tahun pembelajaran 2019/2020 ditolak dan Ha yang berbunyi terdapat pengaruh negatif game online terhadap motivasi belajar siswa di SMKN 1 Narmada tahun pembelajaran 2019/2020 diterima.

Adapun saran yang dapat penulis berikan sehubungan dengan hasil penelitian ini adalah, siswa harus senantiasa memprioritaskan kegiatan yang berkaitan dengan pembelajaran di sekolah dan membatasi waktu untuk kegiatan hiburan yang salah satunya adalah bermain game online. Sekolah agar terus mempertahankan peraturan-peraturan yang meminimalisir dampak negatif game online yaitu salah satunya terkait dengan larangan membawa smartphone di sekolah. Orang tua sebagai garda terdepan agar terus mengontrol dan membatasi anak-anaknya untuk menggunakan media seperti komputer dan smartphone untuk mengakses hal-hal yang negatif yang salah satunya adalah untuk bermain game online.

\section{UCAPAN TERIMA KASIH}

Penulis mengucapkan terima kasih banyak kepada beberapa pihak dan SMAN 1 Narmada yang telah memberikan bantuan data penelitian kepada penulis sehingga penelitian ini dapat terselesaikan dengan baik dan tepat waktu. 


\section{DAFTAR RUJUKAN}

[1] D. E. Kurniawan, "Pengaruh Intensitas Bermain Game Online terhadap Perilaku Prokrastinasi Akademik pada Mahasiswa Bimbingan dan Konseling Universitas PGRI Yogyakarta," $J$. Konseling GUSJIGANG, vol. 3, no. 1, 2017.

[2] Kautsar, "Pengaruh Game Online Terhadap Prestasi Akademik di MAN, Peserta Didik Besar, Aceh," Univ. Islam Negeri Ar-Raniry, 2019.

[3] A. M. Athoillah, "Pengaruh Game Online terhadap Motivasi Belajar Siswa Di SMA Negeri Ambulu Tahun Pelajaran 2015/2016." IAIN JEMBER, 2016.

[4] G. R. Fernando, "Hubungan antar bermain game online dengan perilaku sosial dan prestasi belajar," Skripsi. Bandar Lampung Fak. Sos. dan Polit. Univ. Lampung, 2018.

[5] T. R. Ariantoro, "Dampak Game Online Terhadap Prestasi Belajar Pelajar,” JUTIM (Jurnal Tek. Inform. Musirawas), vol. 1, no. 1, 2016.

[6] D. W. Triatmojo, "Kontribusi Perilaku Game Online Terhadap Motivasi Belajar siswa SMA," Cognicia, vol. 7, no. 4, pp. 527-538, 2019.

[7] S. Suryabrata, "Psikologi Kepribadian Edisi Ke1," Jakarta Rajawali Pers, 2015.

[8] H. B. Uno, "Teori motivasi \& pengukurannya," Jakarta Bumi Aksara, 2008.

[9] M. Dimyati, "Belajar dan pembelajaran," Jakarta: Rineka Cipta, 2006.

[10] K. Ahmad and S. Nurma, "Penerapan Metode Small Group Discussion Terhadap Motivasi Belajar Siswa," Civ. Pendidikan-PenelitianPengabdian Pendidik. Pancasila dan Kewarganegaraan, vol. 8, no. 1, pp. 30-35, 2020.

[11] K. Surbakti, "Pengaruh Game Online terhadap Remaja,” J. Curere, vol. 1, no. 1, 2017.

[12] Angela, "Pengaruh Game Online Terhadap Motivasi Belajar Siswa SDN 015 Kelurahan Sildomulyo Kecamatan Samarinda Ilir," EJournal Ilmu Komun., vol. 1, no. 2, 2013.

[13] A. M. Sardiman, "Interaksi dan motivasi belajar mengajar. Jakarta,” Raja Graf. Persada, 2011.

[14] M. Zuldafrial \& Lahir, "Penelitian kualitatif," Surakarta Yuma Pustaka, 2012.

[15] K. Hijrat and A. Bin Sainudin, "Pengaruh Kecanduan Game Online Terhadap Motivasi Belajar Siswa Kelas VII MTs Negeri Kota Kupang," Al Manar J. Pendidik. Islam, vol. 1, no. 2, pp. 37-48, 2019.

[16] N. Nisrinafatin, "Pengaruh Game Online Terhadap Motivasi Belajar Siswa,” J. Edukasi Nonform., vol. 1, no. 2, pp. 135-142, 2020.

[17] N. L. P. Srinadi, "Analisis pengaruh penggunaan teknologi informasi sebagai media pembelajaran terhadap motivasi belajar siswa," Proc. Konf. Nas.
Sist. dan Inform., 2015. 